\title{
A unifying principle in the study of life on the sea floor
}

\author{
D. J. JONES \\ Department of Biological Sciences, Simon Fraser University; \\ Burnaby, Canada
}

KURZFASSUNG: Ein vereinheitlichendes Prinzip bei der Erforschung des Lebens auf dem Meeresboden. Die Wirkungen der Wasserbewegung auf die Okologie des Meeresbodens werden kurz umrissen. Im Vordergrund stehen Betrachtungen über die Sedimentablagerung und ihre Strukturierung. Die Relationen der benthonischen Lebensgemeinschaften zur Größe der Sedimentpartikel, die eine Funktion der Intensität der Wasserbewegung bilden, werden charakterisiert. Es wird angenommen, daß eine Beschreibung der Wasserbewegung zusammen mit einer Charakteristik der Sedimentbeschaffenheit die Grundlage für eine einheitliche Klassifizierung der Lebensgemeinschaften am Meeresboden darstellen könnte.

\section{INTRODUCTION}

Particulate material in ocean waters can be transported great distances by water movement (e.g. RIEDL 1969, 1971a, b). Most particles eventually sink through the water mass to become deposited on the sea floor where they accumulate as sediment layers. Sea floors may thus be considered as systems of deposition and accumulation, and the sediments so formed, as a characteristic feature of an ocean basin. This paper considers aspects of the relationship between sediment structure and water movements, with their combined effects upon the ecology of the benthos.

The energy required to maintain the movement of ocean waters can be traced to sources located outside the confines of an ocean basin (SverdRup et al. 1963, DuxBURY 1971). Acting together, these external energy sources are sufficient to maintain constant movement of the ocean waters in a marine basin.

\section{RELATIONS BETWEEN SEDIMENT STRUCTURE AND WATER MOVEMENT}

Sediments are formed of particles heavier than sea water. Their tendency to sink is counteracted by the presence of water movements which make them temporarily buoyant, transporting them horizontally over great distances before they settle on the sea floor to contribute to sediment layers. The continuing deposition of sedimentary material depends upon the transportation of sediment components from their source by a constant water flow. Accumulation of these deposits can exceed $1000 \mathrm{~m}$ in deeper 
ocean basins (RILEY \& CHESTER 1971) where they have accumulated over an estimated time span of 100 million years. The accumulation of ocean sediments is thus a dynamic process occurring in an historical sequence, and it is possible to classify such depositionary environments according to their historical location in a continuing sequence of development to the present day.

The prehistoric zone of sedimentation confines the sediments and the water mass within the earth's crust. It is found below the earliest sediments deposited in the basin. This is followed by the historical zone of sedimentation which contains no living systems, but the fossil remains of extinct species are frequently located here. It extends upwards, from the prehistorical zone, usually through progressive younger strata, and its uppermost limit occurs when the presence of living systems is detected. The depth of penetration of living systems into sedimentary strata forms the upper boundary of the historical zone, also the lower boundary of the modern-day zone. The upper limits of the modern-day zone are established at substrate-water interface. A vertical section. through the modern-day zone reveals a thin stratum of living systems often meters or less in thickness but with a horizontal distribution which is presumed to be world wide. The lower limit of the modern-day zone in sediments is defined by FENCHEL \& RIEDL (1970) occurring at "the termination of bacterial activity, the accumulation of poisonous compounds, where the partial pressure of hydrogen may reach one atmosphere".

Future zones of sedimentary environments are represented by sinking particles spread through the water mass above. Hence the physical limits of living systems are delimited within the modern-day zone of most recent sediments. A study of living systems is delimited within the modern-day zone of most recent sedimentation. A consideration of the structure of this zone is presented as a preliminary to a consideration of the life forms associated with it.

The most common method of classification used on unconsolidated sediments is the mechanical analysis of grain size of settled particles. WENTWORTH (1922) modified UDDEN's scheme (1898) and named the grades of particle diameters which were retained within a series of diminishing mesh sizes. His arithmetic series has since been modified as a logarithmic phi scale (KRUMBEIN 1936) which permits a more detailed analysis of the sorting and size distribution of grains as they appear in nature. KRUMBEIN (1939) and MoRgans (1956) review the many other classifications which have been proposed, all of which distinguish between particles of different size contained within sedimentary facies (see also GERLACH 1972).

In the study of benthic biology this method of classification has been adopted to delimit the sedimentary grades forming the physical matrix within which a characteristic living community becomes established (e.g. NEwell 1970). However, it soon becomes apparent to the investigator with direct access to the sea floor that the existing classification based on the WENTWORTH grade scale is not complete. Several important grades of sedimentary facies observed on the ocean floor are missing from the scale. For example, particle sizes larger than a "WENT'WORTH Boulder" are common in most shallow water sublittoral areas. The following extension to the grades of particle sizes is proposed (Table 1): Particles larger than a boulder be called "rock". A rock may be any particle larger than a boulder which is not resting on its original bedding plane. Rocks of this description frequently exceed many hundreds of kilogrammes in shallow 
Table 1

The modefied WENTWORTH grade scale

\begin{tabular}{|c|c|c|c|c|}
\hline Particles & & $\begin{array}{c}\text { Phi } \varnothing \\
\log _{2} \min \end{array}$ & $\mathrm{mm}$ & $\mu \mathrm{m}$ \\
\hline $\begin{array}{l}\text { bedrock } \\
\text { rock }\end{array}$ & & & $>\begin{array}{c}\infty \\
256\end{array}$ & 7256000 \\
\hline boulder & & -8 & 256 & 256000 \\
\hline \multirow{3}{*}{ cobble } & & -7 & 128 & 128000 \\
\hline & & -6 & 64 & 64000 \\
\hline & & -5 & 32 & 32000 \\
\hline \multirow[t]{3}{*}{ pebble } & & -4 & 16 & 16000 \\
\hline & & -3 & 8 & 8000 \\
\hline & & -2 & 4 & 4000 \\
\hline \multirow[t]{3}{*}{ granule } & & -1 & 2 & 2000 \\
\hline & very coarse & 0 & 1 & 1000 \\
\hline & coarse & +1 & $1 / 2$ & 500 \\
\hline \multirow[t]{4}{*}{ sand } & medium & +2 & $1 / 4$ & 250 \\
\hline & fine & +3 & $1 / 8$ & 125.0 \\
\hline & very fine & +4 & $1 / 16$ & 62.5 \\
\hline & coarse & +5 & $1 / 32$ & 31.3 \\
\hline \multirow{4}{*}{ silt } & medium & +6 & $1 / 64$ & 15.6 \\
\hline & fine & +7 & $1 / 128$ & 7.8 \\
\hline & very fine & +8 & $1 / 256$ & 3.9 \\
\hline & coarse & +9 & & 1.95 \\
\hline \multirow{3}{*}{ clay } & medium & +10 & $1 / 1024$ & 0.98 \\
\hline & fine & +11 & & 0.49 \\
\hline & very fine & +12 & $1 / 4096$ & 0.24 \\
\hline colloid & & & $<1 / 4096$ & $<0.24$ \\
\hline
\end{tabular}

water. Substrates larger than rock be called "bedrock". In areas subject to extremes of water movement, all particles including rock are swept into more sheltered areas. Bedrock is exposed to the sea but has not been detached from its original bedding plane. In terms of particle size bedrock becomes the largest particle and forms the uppermost limits of a graded series of facies based on increasing particle size.

\section{EFFECTS OF SEDIMENT STRUCTURE AND WATER MOVEMENT ON BENTHIC ECOLOGY}

ZoBeLL (1938), studying the bacterial flora of marine sediments below the grade of very fine clay (1-5 microns), noted the dramatic increase in bacterial numbers in colloids less than 1 micron in diameter. Spherical bacteria have an estimated average diameter of $1.0 \mu \mathrm{m}$, rod shapes are estimated at $2-5 \mu \mathrm{m}$ long and $0.5 \mu \mathrm{m}$ in diameter (JøRGENSEN 1966). Thus, in terms of size, the bacteria, which are the prevalent life forms in the finest particle grades, are often larger than particles of the substrate they colonize. This important habitat is not considered in the mechanical description of facies proposed by WENTWORTH (1922). The grade colloid, for particles less then "very fine clay", is proposed to complete the series. 
Table 2

Relationship between grade of substrate and velocity of water flow

\begin{tabular}{|ccccl|}
\hline Grade & $\begin{array}{c}\text { Approximate median } \\
\text { particle size } \\
(\mu \mathrm{m})\end{array}$ & $\begin{array}{c}\text { Knots/h } \\
\text { (approx.) }\end{array}$ & $\begin{array}{c}\text { Current } \\
\text { Speed } \\
(\mathrm{cms} / \mathrm{sec})\end{array}$ & Author \\
\hline gravel & 4000 & 2.5 & 128 & STRIDE 1963 \\
sand & $65-2000$ & 1.5 & 77 & STRTDE 1963 \\
mud & $30-65$ & $<1$ & 50 & STRTDE 1963 \\
silt & $2--30$ & 0.004 & $<.2$ & HJuLTROM 1939 \\
clay & $<2$ & - & $<0.01$ & HJut.STROM 1939 \\
\hline
\end{tabular}

All particle sizes known for recent sediments are now included within one classification. Combinations of this particle size range occur in every part of all ocean floors, having developed in the presence of persistent water flows which distribute sedimentary materials.

According to STOKE's equation for settling velocity of suspensions, the heaviest particles sink fastest, nearest their point of origin; the smallest particles, which are usually the lightest, sink more slowly. Fine particles remain in the water column for the longest time period and have the greatest potential for horizontal transport from their source. For example, under perfect conditions, terrigenous materials eroded by the hydrologic cycle would be subject to perfect separation during transportation in the moving water mass, resulting in a linear series of graded facies, outward from the original source of the material at the edge of the sea. Large rocks and boulders would be deposited nearest the shore, the finest clays and colloids furthest from the shore, each deposit being associated with a critical velocity of water movement beyond which it cannot maintain buoyancy in the moving water mass and settles permanently to the bottom. This simplistic model is not observed in nature. The thickness of sediments accumulated in the historical zone is evidence that sediment formation is continuous through time, but the disruptions in a theoretically perfect gradient of sizes, in space, indicates that a discontinuous series of graded facies is laid down at the sediment/ water interface. Many features of a basis, too numerous to list here, are the cause of this uneven distribution of sedimentary grades on the benthos. For examples of geomorphological and biological features in ocean basins see HEEFEN et al. (1959), HEEZEN \& Hollister (1964), Needham (1962), Riedel (1954), Riedl (1971a, b), Hayes (1967), Fleming (1972).

However, the correlation can still be found between the grain size and velocity of flow immediately over the deposit. STRIDE (1963), for example, quotes figures derived from PRATJE (1950) who demonstrated the relationship between the substrate grade and the speed of water passing over it, as shown in Table 2. HJuLstrom (1939), studying finer grain sizes, also confirms the relationships between grade of deposit and the speed of water flow. In his study on the continental shelf in the English Channel and Irish Sea, STRIDE (1963) compared a theoretical distribution of deposit grades, derived from field data on water flow, with the observed distribution of sea floor substrates known for the region. He found a considerable measure of agreement between them. The greater the flow, the coarser the deposit. Eventually, a critical velocity can be 
attained sufficient to transport even the very largest rock, exposing bedrock facies as habitats for colonization by the biota, in areas where the most powerful water movement is found (RIEDL 1971a, b).

The mechanical description of grain size is an indication of other important physico-chemical properties present in a sedimentary environment. Two opposing gradients of physico-chemical factors can be discerned, which vary in magnitude, direction and effect between the various grades of deposit. The examples of these factors, illustrated in Figure 1, are given to indicate how all benthic substrates can be affected by them:

(1) The proportion of grain sizes, their angularity and degree of packing determine the internal volume of interstitial space between the grains within a deposit. In laboratory experiments on porosity, FraSer (1935) quotes Eldus \& LeE (1919) on the following porosity values of sedimentary facies: Coarse sand $(1000 \mu \mathrm{m}$ diameter approx.) 39-41\% "total void" or total space between the grains; medium sand (250 $\mu \mathrm{m}$ diameter approx.) $4-48 \%$; fine sand (125 $\mu$ m approx.) $44-49 \%$; medium silt (15 $\mu \mathrm{m}$ approx.) $50 \%$; medium coarse clay ( $2 \mu \mathrm{m}$ approx.) $95 \%$. Thus in progressively finer sedimentary grades deposited in sheltered areas, an increase in porosity is associated with diminishing particle size as indicated in Figure 1.

(2) Sediment permeability is defined by FRASER (1935) as "allowing passage, especially of fluids, through or into without impairment of structure or displacement of parts", i.e. a substance is termed permeable when it permits a measurable quantity of fluid to pass through in a finite period of time. As a sediment characteristic, the degree of permeability controls the penetration of surface sea water into the sediment layers. This is of great importance when benthic substrates are considered as habitats for living systems. FENCHEL (1969) has shown that linear flow of $8 \mathrm{~cm} / \mathrm{sec}$ over natural sands of median particle diameter $370 \mu \mathrm{m}$ does not penetrate below $0.4 \mathrm{~cm}$ into the surface. $\mathrm{He}$ adds that water movement could be measured at greater depths in coarser grades of material. FrASER (1935) has demonstrated the permeability of gravels to be hundreds of times greater than sand and many thousands of times greater than clay. Thus, as coarser substrates are considered, permeability increases with increasing grain size, as indicated in Figure 1.

(3) A supply of dissolved oxygen in sea water is required by oxidizing communities inhabiting the benthos. Thus, the permeability of a sedimentary grade will also determine the depth to which oxygenated waters will be carried into the substrate and the vertical limits of penetration by oxidizing systems in sedimentary habitats. As sediment grades become finer in more sheltered waters of reduced current velocity, the depth of oxygen penetration into the sediment is reduced, restricting aerobic communities to the uppermost levels of the sediment where dissolved oxygen is present.

In the absence of surface supplies of oxygen, aerobic systems are replaced by the reducing systems which are characteristic of the "black zone" or "sulphide system" described in detail by FENCHEL \& RrEDL (1970). The boundary between the aerobic and anaerobic layers is determined by water flow through interstices of grains and organic content of the sediment. Increase in water flow through the substrate extends the aerobic layers into deeper strata with a corresponding reduction in the volume of sediment occupied by the anaerobic system. In the modern-day sedimentary zone, diminishing water movement can be associated with finer grained sediments containing 


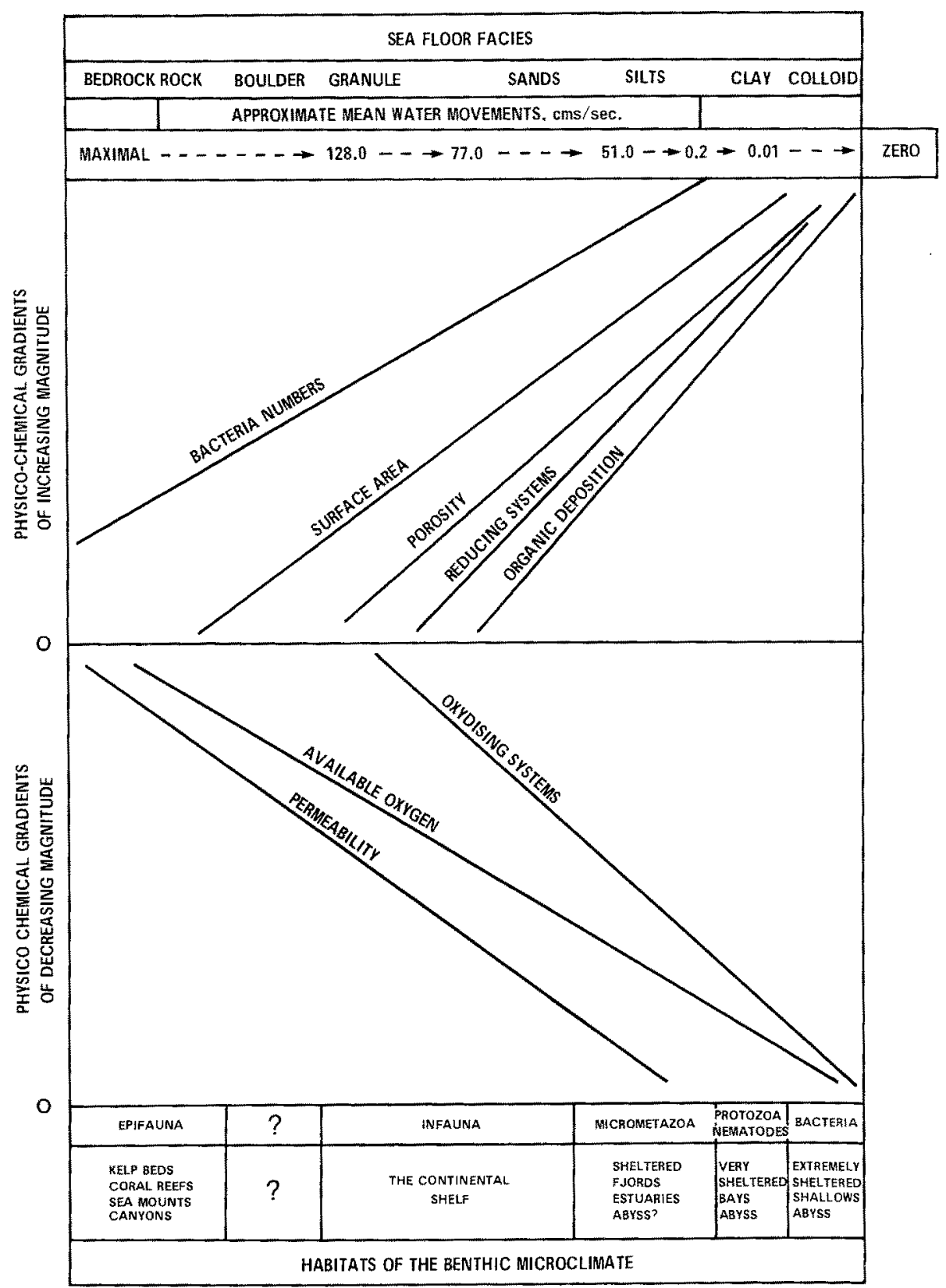

Fig. 1: Physico-chemical gradients associated with the substrate continuum, indicating the range of habitats and their approximate geographical location within an ocean basin 
progressively smaller oxidizing and progressively larger reducing systems. In some extreme cases (SOROKIN 1969), the anaerobic layers in the finest grades of sediment may occupy the whole of the sediment and extend into the water above. In these cases, oxidizing systems are absent.

(4) A small but significant amount of organic material of biological origin is found in sediments finer than approximately $500 \mu \mathrm{m}$ median diameter (NEwELL 1970). The percentage of organic carbon and nitrogen increase logarithmically with decreasing particle size below this grade. Coarser grades than coarse sand approx. $500 \mu \mathrm{m}$ in diameter will contain little or no organic debris carried in from external sources, as indicated in Figure 1.

(5) With decreasing grain size the surface area of the deposit is increased. With increasing surface area, proportionally larger numbers of bacteria have been observed in the deposit (Reuszer 1933, Selman \& Hotchkiss 1938, ZoBell 1938) but this trend can be obscured by a reduction in the numbers of bacteria present in colder or deeper waters.

The potential energy of moving water masses can now be considered in a dual role; as the means of construction of the entire range of sedimentary deposits, and as an important factor in the maintenance of physico-chemical conditions within them.

\section{BENTHIC COMMUNITIES OF THE SUBSTRATE CONTINUUM}

The great range of biotic communities inhabiting the benthos have developed in the presence of environmental parameters related to water movement. For example, on bedrock facies, water movement is maximal, particle size is greatest, oxidizing conditions occur everywhere, oxygen content of the water is highest, there is an abundant exchange of waters over the substrate, both inorganic and organic deposition are negligible. In temperate shallow waters this substrate is the habitat of attached brown algae (see DrEw 1971) and associated with them the diverse invertebrate epifauna. In tropical waters this habitat is occupied by coral reefs which are often considered the most diverse of marine habitats.

The biology of rock, boulders and pebble substrates has received little direct attention (Bacescu 1972, Den Hartog 1972, Gerlach 1972, ZoBell 1972).

Amongst the life forms associated with sands and silt, THorson $(1966,1971)$, for example, reviews the many different communities which can develop, indicating subtle differences in the microclimate presented by the sedimentary habitat which are detected by species colonizing these habitats. FENCHEL (1969) distinguished a sequence of community dominants in fine grades of five deposits. Lamellibranch species predominate in medium and fine sands, accompanied by many species of micrometazoans. Very fine sands represent the lowest limit of distribution of the protozoan ciliates. Clay zones rich in organic detritus are dominated by large numbers of nematodes. The very finest clays and colloids contain the greatest biomass of bacteria which are accompanied by some metazoan species. These examples are taken from an extensive biological literature on benthic communities to indicate optimum ranges of substrate selected for colonization by differing life forms. 


\section{CONCLUSIONS}

In the absence of accurate descriptions of particle distribution within each substrate, much of the published information concerning benthic community structure and distribution cannot be precisely located in this ordination of habitat structure and community composition along a substrate continuum. Until very recently, this deficiency could be largely attributed to the indirect nature of study techniques used in obtaining information concerning the biology of the sea floor; but in situ studies by the scientist/diver are now increasingly common and more detailed descriptions of benthic habitats and the biota within them can be expected. The investigator with direct access to the sea floor soon becomes accustomed to working in the continuing presence of water masses in motion, often to the extent that his investigations of the bitoa omit considerations of the power of moving waters as an environmental variable in his experimental design. However, in this presentation, the formation of sedimentary facies, examples of their geographical distribution and the maintenance of physicochemical conditions within the sedimentary living space have been traced to their source, the energy of water movement. Further study will reveal other causal relationships within benthic living systems, attributable to moving waters.

Future studies on the characteristics of flowing waters near the sea floor could be used as the basis of a universal classification of life forms occupying the substrate continuum below moving ocean waters.

\section{SUMMARY}

1. This paper considers effects of water movement on the ecology of the sea floor and stresses the universal presence of water movement in ocean basins.

2. The modern-day zone of the sedimentary environment is delimited within the ocean basin and the interaction of water movement and sediment deposition discussed.

3. An extension of the WENTWORTH scale of particle size analysis is proposed for use in the description of a substrate continuum based on theoretically perfect hydrologic sorting.

4. Disruptions of a perfect system of deposition in nature are indicated, but general correlations between range of water movement and grade of deposit are established.

5. Examples of physico-chemical gradients which vary with the grade of deposit and velocity of water movements are described. The colonization of these habitats by the biota is indicated.

6. It is suggested that a description of water movements in the vicinity of modern-day sediments could be correlated with the range of life forms observed in the sedimentary continuum, to form a basis for a universal classification of living systems on the ocean floor. 


\section{LITERATURE CITED}

Bacescu, M. C., 1972. Substratum: Animals. In: Marine ecology. Ed. by O. Krnne. WileyInterscience, London 1 (3), 1291-1313.

Drew, E., 1971. Marine botany. In: Underwater science. Ed. by I. D. Woods \& J.N. Lythgoe. Oxford Univ. Press, London, 330 pp.

Duxbury, A. C., 1971. The earth and its oceans. Addison-Wesley, London, $381 \mathrm{pp}$.

Ellis, A. J. \& Lee, C. H., 1919. Geology and ground waters of the western part of San Diego County, California. Supply Pap. U.S. geol. Surv. 446, 121-123.

FENCHEL, T. M., 1969. The ecology of marine microbenthos. IV: Structure and function of the benthic ecosystem, its chemical and physical factors and the microfauna communities with special reference to the ciliated Protozoa. Ophelia 6, 1-182.

- \& RIEDL, R. J., 1970. The sulfide system: a new biotic community underneath the oxydized layer of marine sand bottoms. Mar. Biol. 7, 255-268.

Fleming, N. C., 1972. Geomorphology of the sea floor. In: Underwater science. Ed. by J. D. Woods \& J. N. Lythgor. Oxford Univ. Press, London, $330 \mathrm{pp}$.

FRASER, H. J., 1935. Experimental study of porosity and permeability of clastic sediments. Geology 43, 910-1010.

GerLach, S., 1972. Substratum: General introduction. In: Marine ecology. Ed. by O. Kinne. Wiley-Interscience, London 1 (3), 1245-1250.

HARTOG, C. DEN, 1972. Substratum: Multicellular plants. In: Marine ecology. Ed. by O. Kinne. Wiley-Interscience, London 1 (3), 1277-1289.

HAYES, M. O., 1967. Relationship between coastal climate and bottom sediment type on the inner Continental Shelf. Mar. Geol. 5, 11-132.

Heezen, B. C. \& Holnister, C., 1964. Deep sea current evidence from abyssal sediments. Mar. Geol. 2, 141-174.

- Tharp, M. \& Ewing, M., 1959. The floors of the ocean. 1. North Atlantic. Spec. Pap. geol. Soc. Am. 65, 1-122.

Hjulstrom, F., 1939. Transportation of detritus by moving water 5-31. In: Recent marine sediments. Ed. by P. D. Trask. Dover, New York, 736 pp.

Jørgensen, C. B., 1966. The biology of suspension feeding. Pergamon Press, Oxford, 357 pp.

KRUMBEIN, W. C., 1936. The mechanical analysis of fine grained sediments. J. sedim. Petrol. 2, $140-149$.

- 1939. Graphic presentation and statistical analysis of sedimentary data. In: Recent marine sediments. Ed. by P. D. Trask. Dover, New York, 558-591.

Morgans, J. F. C., 1956. Notes on the analysis of shallow water soft substrata. J. Anim. Ecol. $25,367-387$.

NEWELL, R. C., 1970. Biology of intertidal animals. Logos Press, London, 555 pp.

NeEDHAM, H. D., 1962. Ice-raffed rocks from the Atlantic Ocean off the coast of the Cape of Good Hope. Deep Sea Res. 9, 475-486.

Pratye, O., 1950. Die Bodenbedeckung des Englischen Kanals und die maximalen Gezeitenstromgeschwindigkeiten. Dt. hydrogr. Z. 3, 201-205.

Reuszer, H. W., 1933. Distribution of bacteria and their role in the cycle of life in the sea. III. Distribution of bacteria in ocean waters and muds about Cape Cod. Biol. Bull. mar. biol. Lab., Woods Hole. 65, 480-497.

RIEDEL, W. R., 1954. The age of the sediment collected at Challenger (1875) Stn. 225 and the distribution of Etbmodiscus rex. (RATTray). Deep Sea Res. 1, 170-175.

RiEDL, R., 1969. Marinbiologische Aspekte der Wasserbewegung. Mar. Biol. 4, 62-78.

- 1971a. Water Movement: General Introduction. In: Marine ecology. Ed. by O. KinNe. Wiley-Interscience, London, 1 (2), 1085-1088.

- 1971b. Water Movement: Animals. In: Marine ecology. Ed. by O. KinNE. Wiley-Interscience, London. 1 (2), 1123-1149.

Rtley, J. P. \& Chester, R., 1971. Introduction to marine chemistry. Acad. Press, London, 465 pp. 
SCHwenke, H., 1971. Water Movement: Plants. In: Marine ecology. Ed. by O. Kinne. WileyInterscience, London, 1 (2), 1091-1121.

Selman, A. W. \& Hotchkiss, M., 1938. The oxidation of organic matter in marine sediments by bacteria. J. mar. Res. 1, 101-118.

Sorokin, J. I., 1964. On the primary production and bacterial activities in the Black Sea. J. Cons. perm. int. Explor. Mer, 24, 41-60.

Stride, A. H., 1963. Current swept sea floors near the southern half of Great Britain. Q. Jl. geol. Soc. Lond. 119, 175-199.

Sverdrup, H. U., Johnson, M. W. \& Fleming, R. H., 1963. The oceans, their physics, chemistry, and general biology. Prentice-Hall, Englewood Cliffs, N. J., 1087 pp.

Trorson, G., 1966. Some factors influencing the recruitment and establishment of marine benthic communities. Neth. J. Sea Res. 3, 267-293.

- 1971. Life in the sea. McGraw Hill, New York, 256 pp.

UdDen, J. A., 1898. Mechanical composition of wind deposits. Augustana Libr. Publ. 1.

Wentworth, C. K., 1922. A scale of grade and class terms for clastic sediments. J. Geol. 30, $377-392$.

ZoBelz, C. E., 1938. Studies on the bacterial flora of marine bottom sediments. J. sedim. Petrol. 8, 10-18.

- 1972. Substratum: Bacteria. In: Marine ecology. Ed. by $O$. KinNE. Wiley-Interscience, London, 1 (3), 1251-1270.

Author's address: Dr. D. J. Jones

Department of Biological Sciences

Simon Fraser University

Burnaby 2, B. C.

Canada 